\title{
Micro Abrasive Wear Behaviour Study of Carburization and Ion Plasma Nitriding of P20 Steel
}

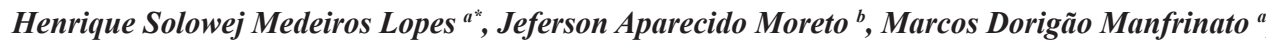 \\ Nilson Cipriano da Cruz ${ }^{c}$, Elidiane Cipriano Rangel ${ }^{c}$, Luciana Sgarbi Rossino $^{a, d}$ \\ ${ }^{a}$ Sorocaba Technological College-FATEC, Av. Engenheiro Carlos Reinaldo Mendes, 2015, \\ 18013-280, Alto da Boa Vista, Sorocaba, SP, Brazil \\ ${ }^{b}$ Federal Institute Goiano - IF Goiano, Rodovia Sul Goiana, Km 01, Zona Rural, \\ 75.901-970, Rio Verde, GO, Brazil \\ 'Paulista State University - UNESP, Av. 3 de Março, 51118087-180, \\ Alto da Boa Vista, Sorocaba, SP, Brazil \\ ${ }^{d}$ Federal University of São Carlos - UFSCar, Rodovia João Leme dos Santos, Km 110, \\ 18.052-780, Bairro do Itinga, Sorocaba, SP, Brazil
}

Received: November 25, 2015; Revised: February 22, 2016; Accepted: April 4, 2016

\begin{abstract}
P20 steel, which is mainly used in plastic molds, was thermochemically treated by ion plasma nitriding and solid and gas carburization. In this work, the solid and gas carburization were performed at $925{ }^{\circ} \mathrm{C}$ for four different durations. The ion plasma nitriding was performed at $520{ }^{\circ} \mathrm{C}$ for four different durations. The thermochemical treatment increased the micro abrasive wear resistance of the studied material. The gas carburizing treatment resulted in a greater surface microhardness. Longer treatment times increased the effectiveness of the thickness layer in all cases. The solid carburization produced a larger thickness layer than the gas carburization and ion nitriding.
\end{abstract}

Keywords: Gas carburizing, Solid carburizing, Ion plasma nitriding, P20 steel, Micro-abrasive Wear

\section{Introduction}

The rapid expansion and importance of the plastic industry have recently caused a considerable increase in the amount of steel required for moulds ${ }^{1}$. Several kinds of steel are applied in the moulds fabrication or to the casting of the low temperature melting point alloy. In addition to P-series steel, martensitic stainless steels (such as AISI 420 or W N. 1.2083) and those hardened by precipitation, similar to the PH 13-8 Mo used to manufacture plastic moulds are commonly used. Tool steels of other series can also be used (e.g., H13 with ESR refining). In this family, the most used steels are P1, P6, P20 and electroslag remelting (ESR) P20. Currently, P1 and P6 steels are not frequently used, and the main material is $\mathrm{P} 20^{2}$.

The main property requirements of mould steel are low hardness at the annealed state (to facilitate the machining process and the forging of hobbing cavities in the matrix), wear and impact resistance, mechanical strength, high polishability and machinability. Usually, steels for moulds are used in the following forms: carburized, nitrided or coated. These treatments are used when greater superficial hardness and better wear, oxidation and erosion resistance are desirable. Otherwise, tempered and annealed steel can be used ${ }^{2-4}$.

The carburization treatment, one of the most known and applied case hardening thermochemical treatments,

*e-mail: henrique_sml@hotmail.com consists of enriching the surface of the carbon material to elevate the hardness and tenacity of the piece, which is then tempered yet maintains its ductile nucleus ${ }^{5}$. The most used media for this treatment are gas and solid. The liquid medium, although efficient and of low cost, is not a currently recommended medium, as it is a pollutant and highly toxic to the environment, requiring constant cleaning and specialised personnel for its performance ${ }^{6}$.

In the nitriding treatment, surface hardening is promoted by nitrogen, which diffuses from the surface of the piece to its interior, reacting with the alloy elements in steel. The objectives are very similar to those of carburization: to produce a wear-resistant surface of high hardness with better resistance to fatigue, corrosion and heat ${ }^{3}$.

The nitriding process includes: gas, liquid, plasma and sulfonitriding. Currently, plasma nitriding is one of the most widely used methods, as this technique demands less time and provides good mechanical properties to the treated material in addition to being environmentally harmless. The process is completely automated ${ }^{3}$.

Additionally, one of the great advantages of plasma nitriding, the process used in this project, is the possibility of controlling the metallurgy of the nitrided layer ${ }^{7}$. The nitriding treatment does not require subsequent tempering, as the obtained hardening does not involve martensite formation but the formation of nitrides below the surface ${ }^{3}$. 
The purpose of this study was to determine the effect of solid carburization, gas carburization and ion nitriding thermochemical treatments on P20 steel and to verify the hardness and wear resistance of the material. The determination of the thermochemical process efficiency is important, as the objective is to increase the useful life of parts used for plastic moulds.

\section{Materials \& Methods}

\subsection{Processing}

To perform this study, tempered and annealed AISI P20 rectangular steel specimens of size $20 \times 35 \times 10 \mathrm{~mm}^{3}$ with a hardness of $34 \mathrm{HRC}$ were used. Table 1 presents the chemical composition (wt $\%$ ) and the nominal chemical composition ${ }^{8}$. The chemical analyses were performed using a Spectromax Ametek model LMF05 optical emission spectrometer in the Laboratory of Materials of the Technological College of Sorocaba (Faculdade de Tecnologia - FATEC Sorocaba).

The solid carburization treatment was performed in the Laboratory of Thermal Treatment of FATEC Sorocaba. In this treatment, coal and calcium carbonate $\left(\mathrm{CaCO}_{3}\right)$ were applied as the chemical activators responsible for the generation of carbon monoxide ( $\mathrm{CO}$ ) during the solid carburization. The composition of the cementing mixture was achieved by sieving coal with standardised granulometric sieves; the mixture was then placed into a properly sealed box with the samples and heated in the furnace at $925^{\circ} \mathrm{C}$ for different treatment times: 2, 4, 6 and 8 hours. After the carburization treatment, the double tempering treatment was performed to increase the hardness of the material. Once the treatment was complete, the furnace was cooled to $860{ }^{\circ} \mathrm{C}$, and the box remained inside for an additional 30 minutes before being cooled to room temperature. After the cooling process, the sample was returned to the furnace for 30 additional minutes at $860{ }^{\circ} \mathrm{C}$ and was then cooled in oil. Annealing was performed for 20 minutes for $180{ }^{\circ} \mathrm{C}$.

The gas carburization thermochemical treatment was conducted at the Thermix Tratamento Térmico de Metais company, which is located in Sorocaba, São Paulo state, Brazil. The treatment was performed at a fixed temperature of $925^{\circ} \mathrm{C}$ with times of: $1,2,3$ and 4 hours. Table 2 presents the treatment parameters. After the gas carburization treatment, a sub-zero treatment was performed, and then, tempering and annealing was conducted to eliminate the retained austenite. The tempering treatment was performed for 30 minutes at $860^{\circ} \mathrm{C}$, and annealing was performed for 20 minutes at $180^{\circ} \mathrm{C}$.

The ion nitriding thermochemical treatment was performed at the MetalPlasma company located in São José dos Campos, state of São Paulo, Brazil, at a fixed temperature of $520^{\circ} \mathrm{C}$ for 2, 4 and 6 hours. Table 3 presents the parameters used for the treatment.

In addition, ion nitriding was performed for 12 hours at the Isoflama company located in Indaiatuba, state of São Paulo, Brazil. The process parameters are listed in Table 4. These parameters were determined based on the parameters usually applied in the treatment of P20 steel.

Before the ion nitriding treatment, the samples underwent sputtering with argon for 3 hours.
Table 1- Chemical composition (wt \%) and nominal chemical composition of W. Nr. 12.311 (AISI P20) ${ }^{[8]}$.

\begin{tabular}{lccccc}
\hline \multicolumn{1}{c}{ Elements } & $\mathbf{C}$ & $\mathbf{M n}$ & $\mathbf{S i}$ & $\mathbf{C r}$ & Mo \\
\hline Nominal & $0.35-0.45$ & $1.30-1.60$ & $0.20-0.40$ & $1.80-2.10$ & $0.15-0.25$ \\
Experimental & 0.434 & 1.49 & 0.306 & 1.81 & 0.190 \\
\hline
\end{tabular}

Table 2- Gas Carburization Treatment Parameters.

\begin{tabular}{lc}
\hline \multicolumn{1}{c}{ Carbon potential inside the furnace } & $\mathbf{1 . 3 0 \%}$ \\
\hline Propane flow rate & $1000 \mathrm{~cm}^{3} / \mathrm{h}$ \\
Methane flow rate & $60 \mathrm{~cm}^{3} / \mathrm{h}$ \\
Working pressure inside the furnace & $6 \mathrm{psi}$ \\
Carburization temperature & $925^{\circ} \mathrm{C}$ \\
Annealing temperature & $180^{\circ} \mathrm{C}$ \\
\hline
\end{tabular}

Table 3- Ion nitriding process parameters.

\begin{tabular}{lc}
\hline \multicolumn{1}{c}{ Atmosphere } & $\mathbf{2 5 \%} \mathbf{H}_{\mathbf{2}}$ and $\mathbf{7 5 \%} \mathbf{~ N}_{\mathbf{2}}$ \\
\hline Work pressure & $300 \mathrm{~Pa}$ \\
Nitriding Temperature & $520{ }^{\circ} \mathrm{C}$ \\
Voltage & $350-450 \mathrm{~V}$ \\
\hline
\end{tabular}

Table 4- Ion nitriding treatment parameters for 12-hour treatment.

\begin{tabular}{lc}
\hline \multicolumn{1}{c}{ Temperature } & $\mathbf{5 2 0}^{\circ} \mathbf{C}$ \\
\hline Atmosphere & $80 \% \mathrm{~N}_{2}$ and $20 \% \mathrm{H}_{2}$ \\
Pressure & $350 \mathrm{~Pa}$ \\
\hline
\end{tabular}

\subsection{Micro-abrasive Wear Test}

Two kinds of tests can be used to study the microwear behavior. They can be performed with fixed and free ball ${ }^{9}$. The fixed ball configuration is used to promote high normal contact load and consequently high stress in the contact. On the other hand, the free ball configuration results in low normal load in the test. The fixed ball test system is broadly used to study the microwear in a variety of materials. The micro abrasive wear tests were carried out using a fixed ball microwear device, as can be seen in Figure $1^{10}$. In this technique, a ball often of bearing steel, is pressed against the test sample in the presence or absence of abrasive slurry. The ball is clamped between coaxial shafts and driven by an electric motor. A flat specimen was mounted horizontally on the ball and is loaded against the ball by a dead weight. This microwear test produces a circular depression in the sample that can be measured (Figure 2) to determine the wear rate of the coating, and under some conditions the substrate material. After wear testing the wear scars was observed by optical microscopy (OM) to identify the dominant wear mechanism. In the present work a 52100 steel ball with $25.4 \mathrm{~mm}$ of diameter was used under a controlled contact load derived only from its weight. The fixed frequency used in this test was $744 \mathrm{rpm}$. The normal load used was $8.3 \mathrm{~N}$ and the test time 10 minutes. The tests were carried out without any type of abrasive or lubricant liquid. After tests all the samples were analysed by OM using an OLYMPUS stereoscope, model SZ61, with a 6 Megapixel camera and Software analysis 2.0, which was used to measure the diameters and the crater radio generated in a coated system 
by rotation of the ball. The wear volume (V) was defined by equation (2.1). The depths of the crater penetration were determined by equation (2.2) ${ }^{11}$ :

$$
\begin{aligned}
& V=\frac{\pi \cdot b^{4}}{64 . r} \quad b<<<<r \\
& H=\sqrt{\frac{V}{\pi \cdot r}}
\end{aligned}
$$

where "b" denotes the diameter of the wear crater and "r" the radius of the standard ball that was used in the test.

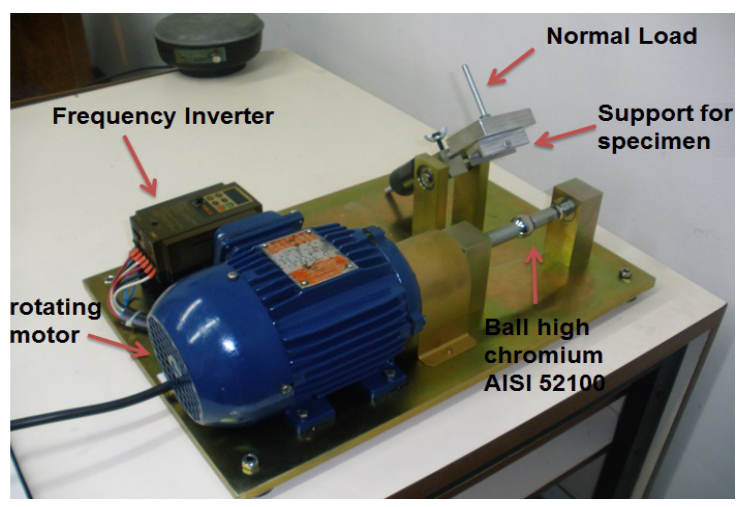

Figure 1 - Microwear device

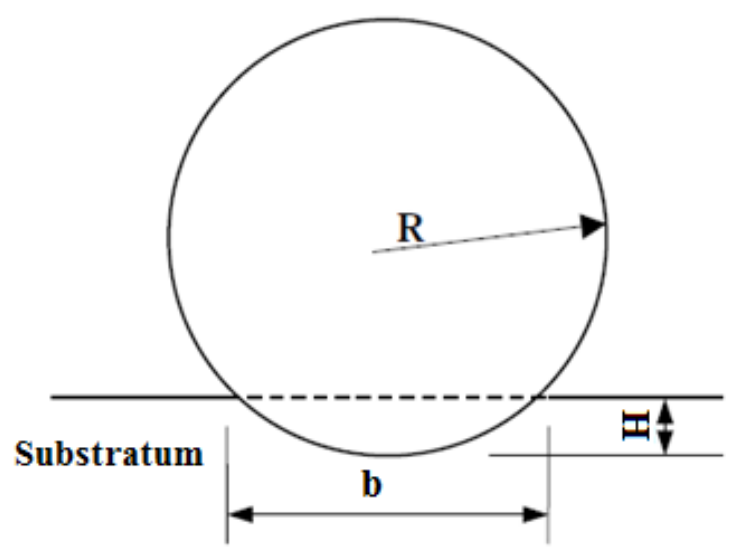

Figure 2 - Circular depression geometry (wear scar) produced in microabrasive wear test

\subsection{Microhardness Test and Metallography Analysis}

After the treatments, microhardness tests were performed to determine the profile and effective thickness of the layer formed by the carburization and nitriding treatments. The microhardness test was performed at the Laboratory of Metallurgy at FATEC Sorocaba, in the state of São Paulo, Brazil, using Mitutoyo equipment model HM 220, a load of $0.2 \mathrm{kgf}$ and an application time of $15 \mathrm{~s}$. The tests were performed according to norm ABNT NBR 13.178/94. The effective layer thickness was determined when its hardness reached that of the substrate.

Metallography analysis of the studied materials was performed according to norm ASTM E 395-00. The metallography was performed using an Olympus optical microscope with an image capturing camera that belongs to the Laboratory of Metallography at the Federal University of São Carlos (Universidade Federal de São Carlos - UFSCar) - Campus of Sorocaba, State of São Paulo, Brazil.

To examine the white layer produced by the nitriding treatment, a JEOL/JSM-6010 scanning electron microscope was used, which was located in the Material Characterisation Multiuser Laboratory at Júlio de Mesquita Filho State University (Universidade Estadual Júlio de Mesquita Filho- UNESP)/ Campus of Sorocaba.

Energy-dispersive X-ray spectroscopy (EDX) analyses were performed with a JEOL/JSM-6010 SEM in the Material Characterisation Multiuser Laboratory at Júlio de Mesquita Filho State University (Universidade Estadual Júlio de Mesquita Filho- UNESP)/Campus of Sorocaba. EDX analyses were conducted to verify the nitrogen and carbon diffusion in the layers formed by the performed thermochemical treatments. The readings were performed at the most external part of the formed layer (Point A), at the end of the layer (Point B) and in the material substrate (Point $\mathrm{C}$ ).

\section{Results \& Discussion}

Figure 3 presents the hardness profiles for the different thermochemical treatments performed. The nuclei of the materials treated by solid and gas carburization after the tempering and annealing treatments exhibited an average hardness of $550 \mathrm{mHV}$. The nuclei of the nitrided samples under the processed condition exhibited an average hardness of approximately $380 \mathrm{mHV}$.

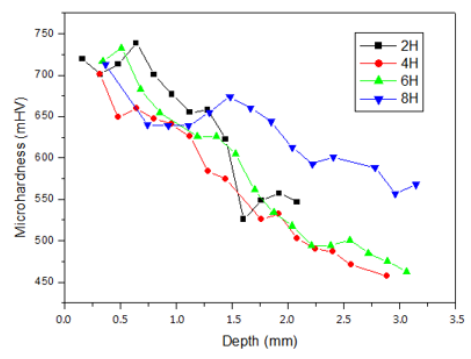

(a) solid carburization

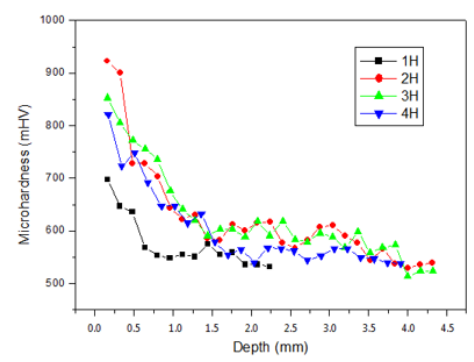

(b) gas carburization

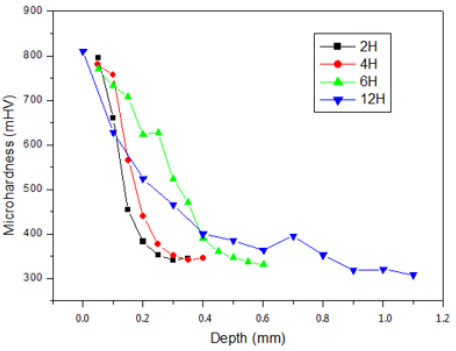

(c) ionic nitriding

Figure 3 - Hardness profile of P20 steel treated by (a) solid carburization, (b) gas carburization and (c) ionic nitriding 
Figure 3 (a) presents the hardness profile of the samples treated with solid carburization. In this treatment, the hardness of all the materials exhibited a significant increase compared with the tempered material without carburization, thus demonstrating the effectiveness of the treatment. The effective layer thickness for the 6- and 8-hour treatments were very similar, with values of 2.73 and $2.78 \mathrm{~mm}$, respectively. For the 4-hour treatment, a slight decrease of the effective layer thickness was observed. The measured value was $2.57 \mathrm{~mm}$. The thinnest layer obtained in this study was $1.75 \mathrm{~mm}$ for the 2-hour treatment. According to Silva and $\mathrm{Mei}^{2}$, depending on the time and temperature conditions applied during solid carburization, the depth of the layer can range from 0.6 to $6.9 \mathrm{~mm}$. It was verified that shorter treatment times result in a greater surface hardness and smaller thickness of the formed layer. However, the shortest treatment times resulted in a steeper decrease in the hardness in relation to the depth of the formed layer.

Figure 3 (b) presents the hardness profile of the samples treated with gas carburization. The effective layer thickness for treatment times of 1, 2, 3 and 4 hours were $0.80,1.10$, 1.40 and $1.70 \mathrm{~mm}$, respectively. The increase of the layer thickness with treatment time is evident. According to Silva and $\mathrm{Mei}^{2}$, depending on the time, temperature and potential of the carbon furnace, the gas carburization treatment can produce layers with thicknesses ranging from 0.5 to $2.0 \mathrm{~mm}$. In the 1- and 2-hour gas carburization treatments, a much steeper decrease of the layer hardness compared with the other treatments was observed. The behaviours of the material for the 3- and 4-hour periods (gas carburization) were similar. For the 2-hour period, a higher surface hardness was observed.

The thickness values of the experimentally formed layers for the gas carburization treatments performed in this study were analytically analysed by Oliveira ${ }^{12}$ using Fick's diffusion law and the Arrhenius law. The results obtained from the theoretical and practical analyses are presented in Table 5, demonstrating the effectiveness of the method applied to the determination of the layer depth. The layer thickness results determined by the practical test were consistent with the theoretically defined layer thickness, thus demonstrating the efficiency of the performed thermochemical treatment ${ }^{12}$.

The obtained results indicate that the surface hardness of the layers produced by gas carburization is higher than the layers produced by solid carburization. Gas carburization generated layers of smaller thickness compared with solid carburization. According to Silva and Mei ${ }^{2}$, the gas carburization treatment produces greater surface hardness and smaller depths in the carburized layer compared with

Table 5- Results obtained by different analysis techniques for the diffusion coefficient of carbon obtained by the gas carburization of AISI P20 steel.

\begin{tabular}{ccc}
\hline $\begin{array}{c}\text { Treatment } \\
\text { Time (h) }\end{array}$ & $\begin{array}{c}\text { Theoretical } \\
\text { Thickness }(\mathbf{m m})\end{array}$ & $\begin{array}{c}\text { Experimental } \\
\text { Thickness (mm) }\end{array}$ \\
\hline 1 & 0.80 & 0.80 \\
2 & 1.00 & 1.10 \\
3 & 1.20 & 1.40 \\
4 & 1.60 & 1.70 \\
\hline
\end{tabular}

the solid carburization treatment, thus corroborating the obtained results.

Figure 3 (c) presents the hardness profiles of the nitrided samples for times of 2, 4, 6 and 12 hours. The surface hardness of all materials treated by ion nitriding was higher than that of the untreated material, demonstrating the effectiveness of the treatment. The diffusion layer thicknesses of the samples treated for 2, 4, 6 and 12 hours were approximately 0.19 , $0.25,0.45$ and $0.80 \mathrm{~mm}$, respectively, which indicates the increase of nitrogen diffusion as the treatment time increases. As observed in other treatments, longer treatment times resulted in smaller surface hardnesses and greater depths of the formed layer. The 2-hour treatment essentially resulted in the same hardness as the 12-hour treatment. However, the decrease of hardness with depth for the sample treated for 2 hour was much steeper compared with that of the sample treated for 12 hour.

Figure 4 shows the metallography of the white layer of all the samples treated with ion nitriding for different treatment times: (a) 2 hours, (b) 4 hours, (c) 6 hours and (d) 12 hours.

The white layer formed in the nitrided samples was examined by SEM. For the 2-hour sample, a 7.15- $\mu \mathrm{m}$ white layer was formed (a). In the 4-hour sample, this value increased to $9.35 \mu \mathrm{m}$ (b); for the 6-hour sample, this value increased to $11.5 \mu \mathrm{m}$ (c) and for the 12-hour sample, this value increased to $9.8 \mu \mathrm{m}(\mathrm{d})$. Note that the 12-hour nitriding treatment was performed with parameters different from those of the other treatments.

The significant increase of the white layer thickness with time is noticeable. The white layer, generally with a thickness greater than $25 \mu \mathrm{m}$, exhibits good gripping resistance, reduces the coefficient of friction, improves the fatigue resistance in corrosive environments and the corrosion resistance but exhibits a low hardness ${ }^{2}$. "White layer" or "compound layer" are the terms used to denote the most superficial layer formed by iron nitrides. In metallography analysis, this region exhibits a white colour because it does not react with the chemical reagent. The layer is composed of two types of nitrides: $\varepsilon$ and $\gamma$ '. The first type exhibits a nitrogen content higher than $8.0 \mathrm{wt} \%$ and is fragile. The second type has a nitrogen content between 5.9 and $6.5 \mathrm{wt} \%$ in weight and is ductile. The white layer also exhibits good wear and corrosion resistance ${ }^{13}$.

The diffusion layer, which is below the white layer, is composed of $\gamma$ ' nitrides (needle-shaped) and nitrogen dissolved in the iron matrix and exhibits good fatigue resistance ${ }^{13}$.

The chemical compositions of the layers formed by all the thermochemical treatments were measured by SEM/EDS, and the results are presented in Table 6 . This analysis is an important qualitative analysis for the observation of carbon and nitrogen diffusion along the thickness, starting from the surface of the material.

The effectiveness of the applied treatments was evident, as the $\mathrm{wt}^{\mathrm{O}} \%$ of the element measured at the top of the layer was much higher than the measurement in the substrate. As the reading point approached the substrate, this percentage decreased.

Figure 5 shows the surface hardness of all the materials according to the treatment time. Longer treatment times do not always result in higher surface hardnesses. With the 


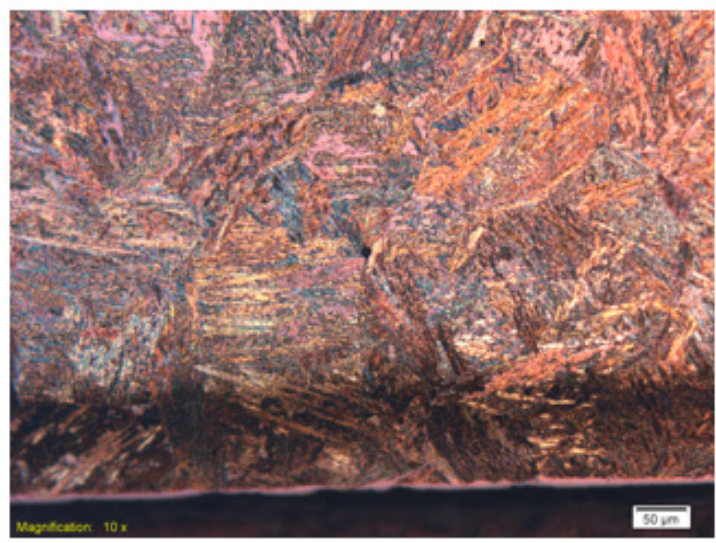

(a) 2 hours

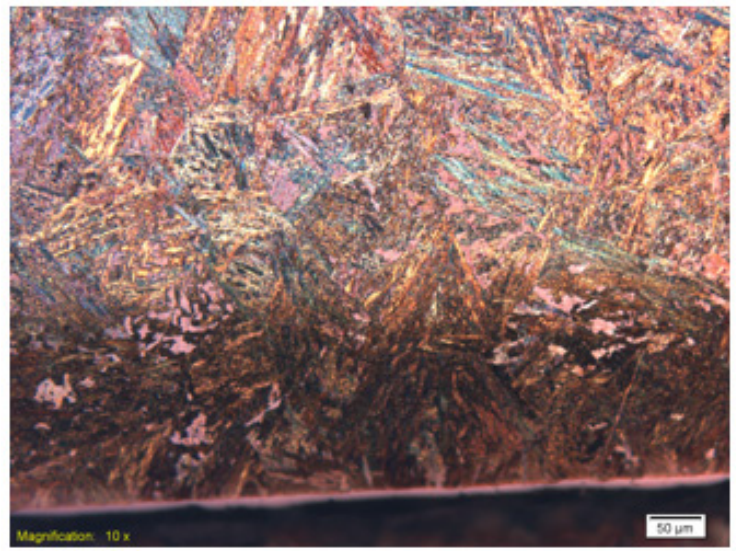

(c) 6 hours

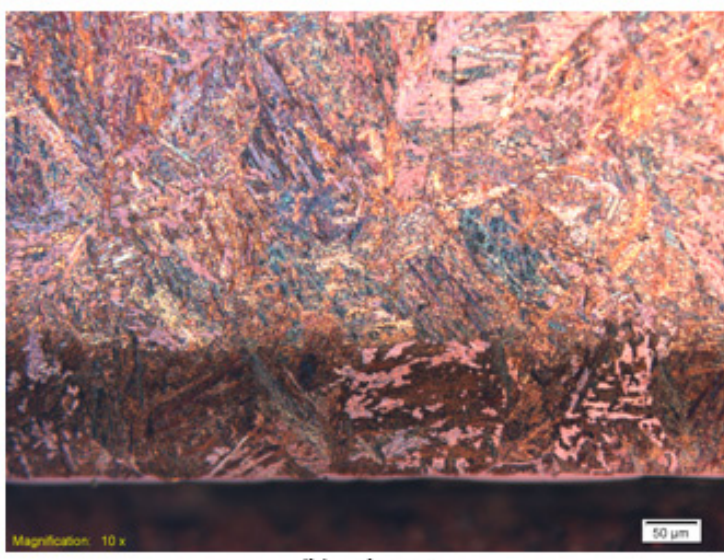

(b) 4 hours
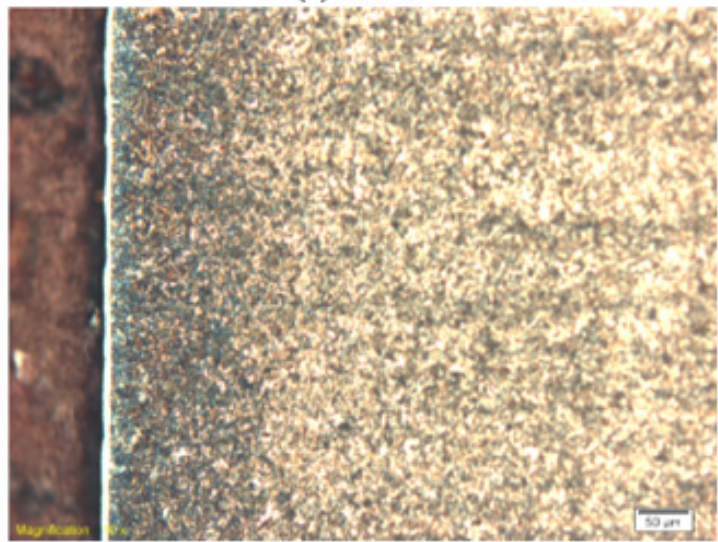

(d) 12 hours

Figure 4 - Micrography of the nitrided layer treated for (a) 2 hours, (b) 4 hours, (c) 6 hours and (d) 12 hours

Table 6- Chemical composition of layers formed.

\begin{tabular}{lrcc}
\hline \multicolumn{1}{c}{ Treatment } & Point A & Point B & Point C \\
\hline Solid carburization 2 hours & $8.3 \mathrm{wt} \% \mathrm{C}$ & $5.4 \mathrm{wt} \% \mathrm{C}$ & $4.1 \mathrm{wt} \% \mathrm{C}$ \\
Solid carburization 4 hours & $8.4 \mathrm{wt} \% \mathrm{C}$ & $6.3 \mathrm{wt} \% \mathrm{C}$ & $3.9 \mathrm{wt} \% \mathrm{C}$ \\
Solid carburization 6 hours & $10.5 \mathrm{wt} \% \mathrm{C}$ & $6.9 \mathrm{wt} \% \mathrm{C}$ & $4.0 \mathrm{wt} \% \mathrm{C}$ \\
Solid carburization 8 hours & $11.4 \mathrm{wt} \% \mathrm{C}$ & $7.5 \mathrm{wt} \% \mathrm{C}$ & $6.0 \mathrm{wt} \% \mathrm{C}$ \\
Gas carburization 1 hour & $11.9 \mathrm{wt} \% \mathrm{C}$ & $5.7 \mathrm{wt} \% \mathrm{C}$ & $2.4 \mathrm{wt} \% \mathrm{C}$ \\
Gas carburization 2 hours & $9.7 \mathrm{wt} \% \mathrm{C}$ & $4.9 \mathrm{wt} \% \mathrm{C}$ & $3.6 \mathrm{wt} \% \mathrm{C}$ \\
Gas carburization 3 hours & $11.4 \mathrm{wt} \% \mathrm{C}$ & $7.8 \mathrm{wt} \% \mathrm{C}$ & $4.5 \mathrm{wt} \% \mathrm{C}$ \\
Gas carburization 4 hours & $10.1 \mathrm{wt} \% \mathrm{C}$ & $7.9 \mathrm{wt} \% \mathrm{C}$ & $9.0 \mathrm{wt} \% \mathrm{C}$ \\
Ion nitriding 2 hours & $6.7 \mathrm{wt} \% \mathrm{~N}$ & $3.5 \mathrm{wt} \% \mathrm{~N}$ & $1.9 \mathrm{wt} \% \mathrm{~N}$ \\
Ion nitriding 4 hours & $7.9 \mathrm{wt} \% \mathrm{~N}$ & $4.1 \mathrm{wt} \% \mathrm{~N}$ & $1.7 \mathrm{wt} \% \mathrm{~N}$ \\
Ion nitriding 6 hours & $6.6 \mathrm{wt} \% \mathrm{~N}$ & $3.8 \mathrm{wt} \% \mathrm{~N}$ & $1.3 \mathrm{wt} \% \mathrm{~N}$ \\
Ion nitriding 12 hours & $7.5 \mathrm{wt} \% \mathrm{~N}$ & $3.9 \mathrm{wt} \% \mathrm{~N}$ & $1.5 \mathrm{wt} \% \mathrm{~N}$ \\
\hline
\end{tabular}

exception of gas carburization for 1 hour, longer treatment time resulted in reduced surface hardness for the solid and gas carburization treatments. For ionic nitriding, a decrease in the surface hardness was observed as the treatment time increases, which increases again with 12 hours of treatment.

Wolfart ${ }^{14}$, Reis et al., ${ }^{15,16}$ and Caetano et al., ${ }^{17}$ obtained similar results, demonstrating that low temperatures result in a high concentration of nitrogen at the surface, thus increasing its hardness. As the temperature is increased, the concentration decreases, diffusing to the substrate and causing the increase of diffusion depth and decrease of surface hardness.

Figure 6 shows the depth of the treated layer as a function of the thermochemical treatment time. It is evident that longer treatment times result in the greater thicknesses of the formed layer. As observed by Manfrinato ${ }^{18}$, longer 


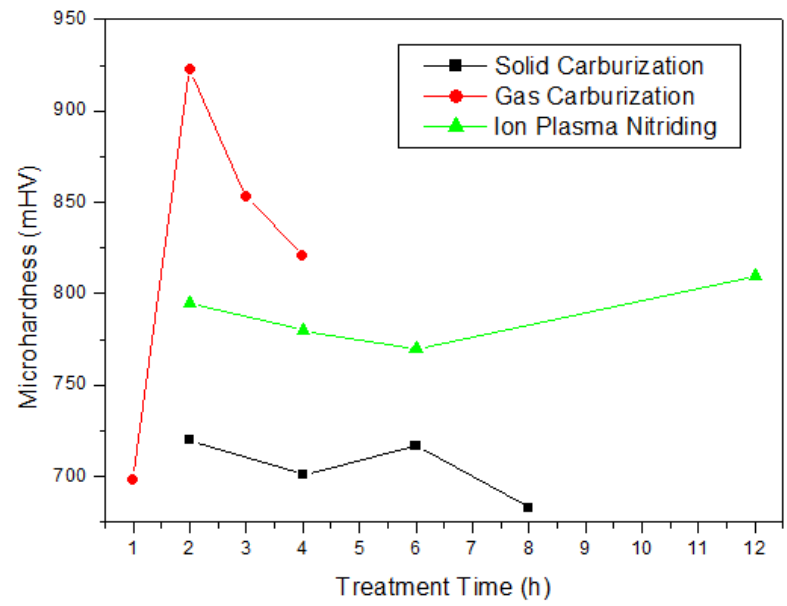

Figure 5 - Micro-scale superficial hardness as a function of treatment time for all the samples

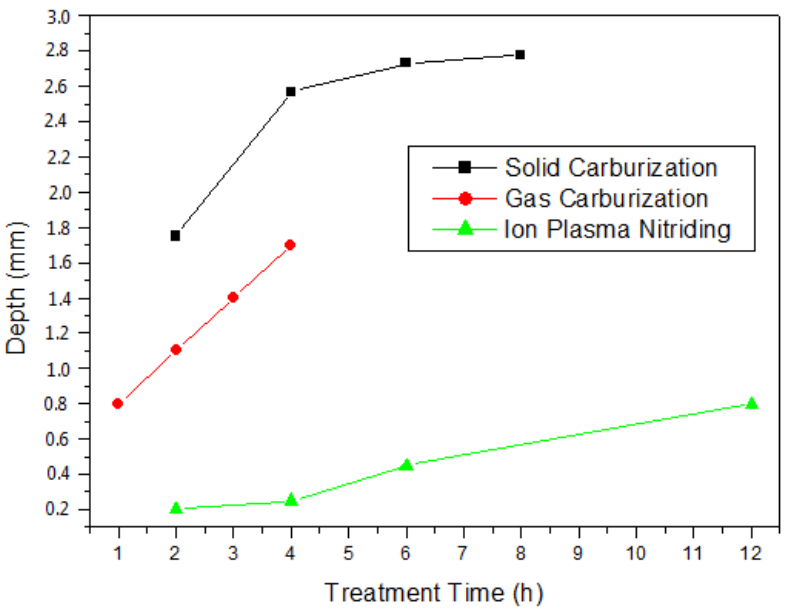

Figure 6 - Layer depth as a function of the time of applied thermochemical treatment

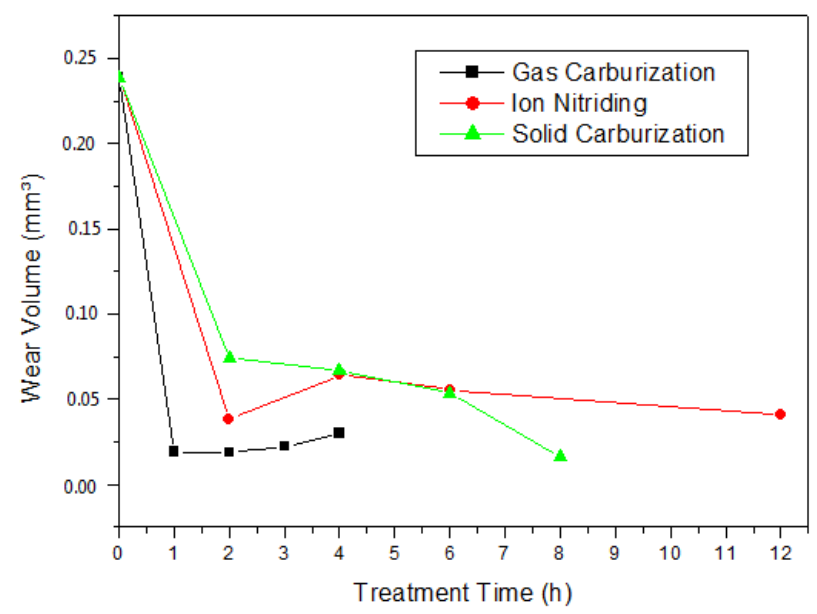

Figure 7 - Wear volume by treatment time for all thermochemical treatments applied 
treatment times result in larger diffusion coefficients, i.e., a greater thickness of the formed layer.

The wear tests were performed to analyse the effectiveness of the performed thermochemical treatments in relation to the wear resistance of the study material. Table 7 indicates that none of the tests reached the substrate, i.e., the obtained wear resistance is directly linked to the layers formed by the treatments.

Figure 7 presents the wear volume as a function of the different times and types of thermochemical treatment applied.
The treatments that presented the best wear resistance were the 2-hour gas carburization, with a wear volume of $0.019 \mathrm{~mm}^{3}$ due to its high surface hardness and the 8-hour solid carburization, with a wear volume of $0.017 \mathrm{~mm}^{3}$ due to its uniform hardness in relation to the carburization depth, as observed in Figure 7.

Analysing the wear scar (Figure 8), it is possible observe that the active wear mechanism was abrasive. In microabrasive wear, the wear mode can occur by scratching, rolling or a combination of both ${ }^{19}$. The wear rolling occurs when abrasives

Table 7-Comparison of cap height formed by the wear tests with the depth of the layer generated by the thermochemical treatments.

\begin{tabular}{lcc}
\hline \multicolumn{1}{c}{ Treatment } & Cap Height $(\mathbf{m m})$ & Layer Depth $(\mathbf{m m})$ \\
\hline Solid Carburization 2 hours & 0.043 & 1.75 \\
Solid Carburization 4 hours & 0.040 & 2.57 \\
Solid Carburization 6 hours & 0.036 & 2.73 \\
Solid Carburization 8 hours & 0.020 & 2.78 \\
Gas Carburization 1 hours & 0.022 & 0.80 \\
Gas Carburization 2 hours & 0.022 & 1.10 \\
Gas Carburization 3 hours & 0.023 & 1.40 \\
Gas Carburization 4 hours & 0.027 & 1.70 \\
Ion nitriding 2 hours & 0.031 & 0.20 \\
Ion nitriding 4 hours & 0.040 & 0.25 \\
Ion nitriding 6 hours & 0.037 & 0.45 \\
Ion nitriding 12 hours & 0.032 & 0.90 \\
\hline
\end{tabular}

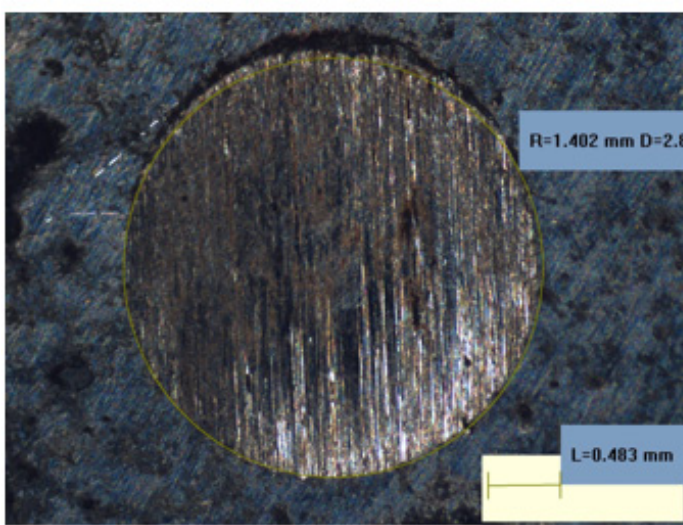

(a) base material

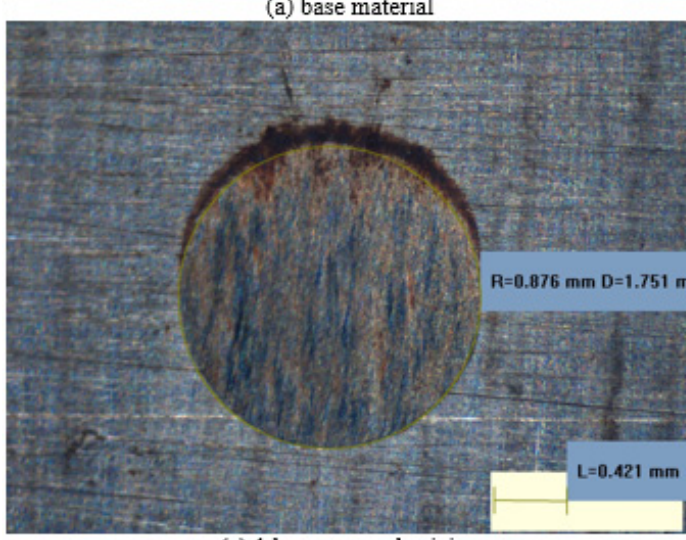

(c) 1 hour gas carburizing

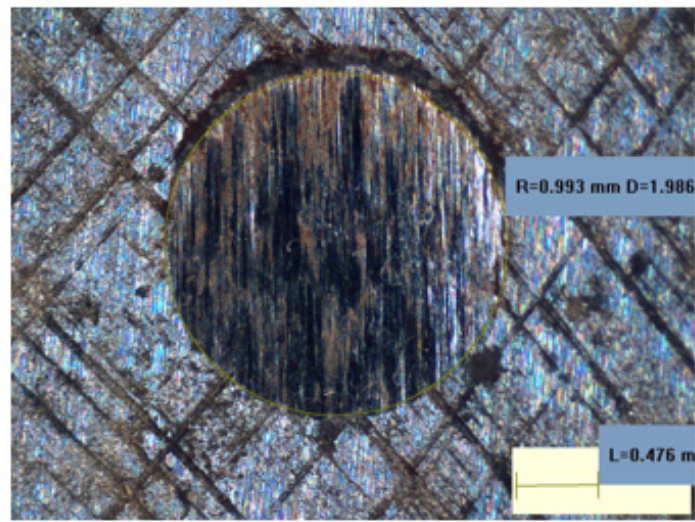

(b) 2 hours solid carburizing

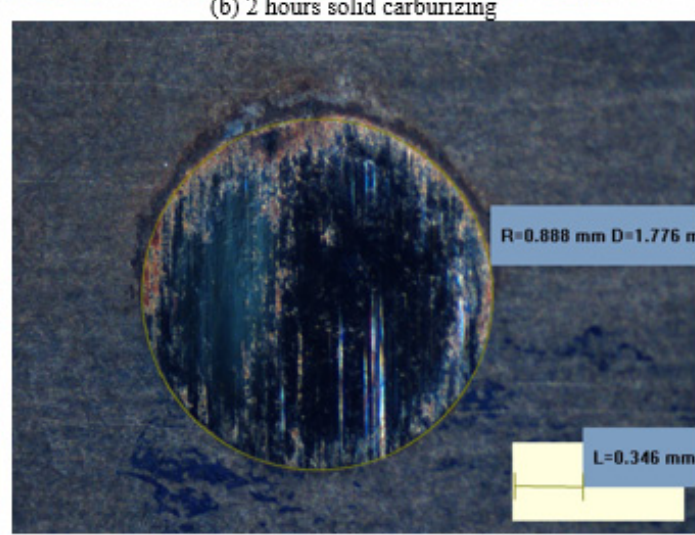

(d) 2 hours nitriding surface treatment

Figure 8 - Wear scars produced in the microabrasive wear test by (a) base material (b) 2 hours solid carburizing (c) 1 hour gas carburizing and (d) 2 hours nitriding surface treatment 
roll over the wear surface, while the wear scratching occurs when the abrasives sliding over the wear surface ${ }^{19,20}$.

In the base material (Figure 8a) and solid carburizing wear scar (Figure 8b), occurred a mix wear mode by rolling and scratching, while in the gas carburizing (Figure 8c) and nitriding wear scar (Figure 8d), the rolling wear mode is predominant. As the microabrasive wear tests were carried out without slurry or abrasive, the grooves were produced by high particle detached from layer produced by surface treatment and present in the contact interface.

The oxidation observed in the sliding wear can be explained in that the abrasive particles produced in the wear region can brake into small pieces and its oxidize fast due to large exposed area, also being promoted by heat generated by plastic strain that the specimen or particle suffer.

According to Rosa ${ }^{6}$, the solid carburization process faces some difficulties for its execution, especially if placed in a production line, where the main factor is productivity and quality control. However, this process is still highly recommended for some parts and occasions. Rosa ${ }^{6}$ also verified that the advantages of the gas carburization process are very gratifying, as it allows the control of the process and also better productivity. The disadvantages are the required specialised personnel and the expensive equipment; however, when the advantages of the process are analysed, the process is concluded to be satisfactory ${ }^{6}$.

For nitriding, Corazza ${ }^{21}$ observed an improvement of the heat transfer in the mould during the injection process compared with the untreated mould, which generates a shorter cooling cycle. In addition, the reduction of the mould temperature during the process was observed when the nitriding treatment was applied. These improvements can reduce the total cycle time of the injection process by up to $12 \%$ with no decrease in the final quality of the injected part. Furthermore, during nitriding, the parts undergo less warping, as low temperatures are used. There is also excellent control of the nitrided layer. However, the necessary equipment for this treatment is costly, and the process is usually slow ${ }^{21}$.

\section{Conclusions}

The solid carburization treatment resulted in the greatest layer thickness for the same treatment time. After 2, 4, 6 and 8 hours, the depths were $1.75,2.57,2.73$ and $2.78 \mathrm{~mm}$, respectively. The gas carburization treatment combined high surface hardness, reaching $923 \mathrm{mHV}$ for the 2-hour treatment, with considerable layer depth values of $0.80,1.10,1.40$ and $1.70 \mathrm{~mm}$ for treatments of 1, 2, 3 and 4 hours, respectively. The plasma nitriding treatment resulted in small layer depths of 0.19 , $0.25,0.45$ and $0.80 \mathrm{~mm}$ for times of $2,4,6$ and 12 hours, respectively.

As observed, shorter treatment times produced higher surface hardness because of the concentration of the surface hardening element. Longer treatment times facilitated the diffusion of hardening elements to the substrate, decreasing the surface hardness and increasing the depth of the formed layer.
All the thermochemical treatments performed in this study considerably increased the wear resistance of the studied material. The performed wear tests demonstrated that solid carburization for 8 hour resulted in the optimal results, and a similar value was obtained with gas carburization for 2 hour. However, in general, gas carburization produced the best wear resistance.

The wear volume obtained by the gas carburization and ion nitriding treatments exhibited similar behaviour, i.e., shorter treatment times resulted in smaller wear volumes because of the greater surface hardness. For the solid carburization treatment, the material that exhibited the best results was that treated for 8 hour because of the hardness uniformity and high layer depth. High wear resistance may be directly associated to high surface hardness. However, it was observed that uniform layer hardness also produces high wear resistance, generated by the longer treatment time.

In addition to the wear resistance of the material, the effectiveness of the treatment as a whole should be considered to determine the most adequate treatment needed. Although the ion nitriding treatment resulted in a smaller wear resistance when compared with the carburization treatments, this approach produces decreased warping of the part, as this approach requires lower temperatures. Plastic moulds are pieces with many details and minimum tolerance; therefore, lower warping is essential in these cases, among other factors.

Nitriding also decreased the total time of the injection cycle, as this treatment allows greater heat transfer in the mould, and, consequently, lower temperatures, reducing the cooling time of the part. Obtaining smaller times in the injection cycle may be crucial in the selection of the treatment.

The solid carburization treatment is by far the least expensive, as it uses simple equipment and does not require specialised personnel, resulting in interesting properties. However, there is no control of the formed layer, and as it requires tempering, this treatment produces greater warping of parts compared with nitriding. The gas carburization treatment also produces greater warping; however, there is great control of the process, and the equipment and required personnel are less costly compared with those required by nitriding.

The determination of the most adequate treatment among those studied here for a given application should be analysed by considering the results and information presented here.

\section{Acknowledgements}

The authors thank the Federal University of São Carlos (Universidade Federal de São Carlos - UFSCar), Júlio de Mesquita Filho State University (Universidade Estadual Júlio de Mesquita Filho - UNESP), the Technological College of Sorocaba (Faculdade de Tecnologia de Sorocaba) for the availability of laboratories, the São Paulo Research Foundation (Fundação de Amparo à Pesquisa do Estado de São Paulo - Fapesp) for the granted fellowship and Federal Institute Goiano (Instituto Federal Goiano) for supporting the translation of the manuscript. 


\section{References}

1. Sors L. Moldes e matrizes. São Paulo: Hemus; 2002.

2. Silva AL, Mei PR. Aços e ligas especiais. 3a ed. São Paulo: Blucher; 2010.

3. Chiaverini V. Aços e ferros fundidos. 4a ed. São Paulo: ABM; 1977.

4. ASM International Handbook Committee. Corrosion: Materials [Internet]. Ohio: Materials Park; 2005. Vol. 13B. [cited 2015 Nov 21]. Available from: http://www.asminternational.org/ documents/10192/1849770/ACFAB43.pdf

5. Yoshida A. Nova mecânica industrial: metais, ligas e tratamento térmico. Rio De Janeiro: Esparsa; 1990.

6. Rosa MF. Estudo do tratamento térmico-análise das vantagens e desvantagens dos processos de têmpera por indução $e$ cementação [Monograph]. Novo Hamburgo: Universidade Feevale; 2012.

7. Edenhofer B. Physical metallurgical aspects of ionitriding - Part 1. Heat Treatment of Metals. 1974;1(1):23-28.

8. AISI. Special Steels [Internet]. [cited 2014 Jul 08]. Available from: http://www.favorit.com.br/produtos/acos-ferramenta/ aco-aisi-p20/

9. Gee MG, Gant AJ, Hutchings IM, Kusano Y, Schiffman K, van Acker K, et al. Results from an interlaboratory exercise to validate the micro-scale abrasion test. Wear. 2005;259:27-35. http://dx.doi.org/10.1016/j.wear.2005.02.092

10. Santos WC, Pereira Neto JO, Silva RO, Rodrigues G, Moreto JA, Manfrinato MD, et al. Apparatus development and study of abrasive microwear behaviour of quenched and tempered AISI 420 steel. Matéria (Rio de Janeiro). 2015;20(2):304-315. http://dx.doi.org/10.1590/S1517-707620150002.0031.

11. Rutherford KL, Hutchings IM. A micro-abrasive wear test with particular application to coated systems. Surface and Coatings Technology. 1996;79(1-3):231-239. http://dx.doi. org/10.1016/0257-8972(95)02461-1.
12. Oliveira CT. Determinação da espessura da camada produzida por cementação gasosa em Aço p20 através da teoria da difusão [Monograph]. Sorocaba: Fatec; 2014.

13. Vendramin JC. Seleção de Materiais Para Nitretação. Indaiatuba (SP): ISOFLAMA Industria e Comércio De Equipamentos; 2008.

14. Wolfart Jr M. Nitretação a plasma do aço ABNT 316 L em Baixas Temperaturas [Thesis]. Porto Alegre: Universidade Federal do Rio Grande do Sul; 2002.

15. Reis RF, Schreiner WH, Borges PC. Nitretação do aço inoxidável AISI $316 \mathrm{~L}$ a altas temperaturas: influência na camada nitretada. Revista Brasileira de Aplicações a Vácuo. 2006;25(3):183-187. http://dx.doi.org/10.17563/rbav.v25i3.65

16. Reis RF, Maliska AM, Borges PC. Nitretação a plasma do aço ISO 5832-1: influencia de temperaturas elevadas de processamento. Revista Brasileira de Aplicações de Vácuo. 2007;26(4):205-210. http://dx.doi.org/10.17563/rbav.v26i4.251

17. Caetano RR, Franco Jr. AR, Pìnedo CE. Características de formação da austenita expandida na nitretação por plasma do aço inoxidável austenitico AISI 316 grau ASTM F138. Mogi das Cruzes (SP): Núcleo de Pesquisas Tecnológicas da Universidade de Mogi das Cruzes; 1998.

18. Manfrinato MD. Influência da nitretação a plasma no comportamento em fadiga dos aços inoxidáveis austeniticos AISI 304 e 316 [Dissertation]. São Carlos (SP): Universidade de São Paulo; 2006.

19. Cozza RC, Recco AA, Tschiptschin AP, Souza RM, Tanaka DK. Análise comportamental dos coeficientes de atrito e desgaste de sistemas revestidos submetidos a desgaste microabrasivo. Tecnologia em Metalurgia, Materiais e Mineração. 2010;6(4):237-244. http://dx.doi.org/10.4322/tmm.00604010.

20. Cozza RC, de Mello JD, Tanaka DK, Souza RM. Relationship test severity and wear mode transition in microabrasive wear tests. Wear. 2007;263(1-6):111-116. http://dx.doi.org/10.1016/j. wear.2007.01.099

21. Corazza EJ. Influência do tratamento de nitretação em cavidades de aço p20 de moldes de injeção de termoplásticos [Dissertation]. Joinville: Universidade Da Região De Joinville; 2012. 